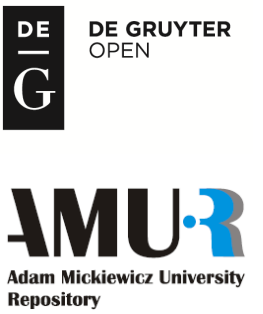

\title{
SANSELIGE VERDENER. POETIK OG REPRÆSENTATION I DEA TRIER MØRCHS REJSEBØGER
}

\author{
SYLWIA IZABELA SCHAB \\ Adam Mickiewicz University in Poznan
}

ABSTRACT The article deals with three travel books (Sorgmunter socialisme (1968), Polen (1970) and Da jeg opdagede Amerika (1986)) written by a Danish graphic designer, writer and political activist Dea Trier Mørch (1941-2001). In focus of the text analysis is the question of poetological aspects, a.o. of the position of the three texts in relation to travel books as a genre and the narrative strategies, which are used by the author to represent the visited countries. As the analysis will reveal, Mørch (as author and protagonist) can be understood as a modern sentimental traveler - both in terms of the structure of her narratives and the existential dimension of her travels.

\section{1. „DEN SKRIVENDE GRAFIKER/DEN TEGNENDE FORFATTER" (SØHOLM 1991: 390)}

Dea Trier Mørch (1941-2001) var i sin tid kendt som både kunstner, forfatter og politisk aktivist, og det var netop de tre områder hun søgte at forene $\mathrm{i}$ sit offentlige liv. Hun voksede op $\mathrm{i}$ et hjem præget af venstreorienteret livsanskuelse, hvilket har påvirket hele hendes senere offentlige aktivitet. Hun var ikke alene medstifter og en af hovedkræfterne bag det socialistisk prægede kunstnerkollektiv Røde Mor (1969-1978), men også medlem af Danmarks Kommunistiske Parti (1972-82). Som sekstenårig blev hun optaget på Kunstakademiet, hvor hun dyrkede abstrakt kunst ${ }^{1}$, men hun var også meget aktiv i studenterforeningen (som hun som nittenårig blev formand for). Det er netop gennem sit virke inden for studenterorganisationen, hun kom på sine studieture til udlandet, som igen resulterede i hendes litterære debut

\footnotetext{
${ }^{1}$ Hun var elev af professor Egill Jacobsen (1910-1998), et af medlemmerne af COBRAgruppen.
} 
i 1968. Mørch fik sit folkelige gennembrud med romanen Vinterbørn (1976) ${ }^{2}$, som både viste hendes socialrealistiske valgslægtskaber og markerede en ny måde at skildre graviditet, fødsel og det at være kvinde og mor på.

Hendes forfatterskab kan inddeles i fire perioder med udgangspunkt i forfatterens måde at anskue verden på samt placere sig selv som fortæller (se Agger 1981; Jensen 1985). Den første periode er karakteriseret ved at Mørch som forfatter ( $\mathrm{og}$ som fortæller) betragter tingene fra afstand, men samtidig $\emptyset$ nsker at blive en del af den beskrevne virkelighed. Herunder hører hendes to første udgivne tekster: rejsebøgerne Sorgmunter socialisme (1968) og Polen (1970) og senere udgivet Da jeg opdagede Amerika (1986), som står i centrum for senere analyse i dette bidrag. 70'erne åbner for et nyt kapitel, hvor Mørch tager nogle emner op, som hun i meget højere grad har personligt kendskab til, og som derfor er karakteriseret ved større nærhed, intimitet og indlevelsesevne, såsom graviditet, fødsel, moderskab, barndom i bedsteforældrenes skød, partnerskab samt de konflikter, som præger dagliglivet. Denne fase, som romanen Vinterbørn (1976) kan anses som repræsentativ for, dyrkes under overskrifterne kollektivisme og det kollektive perspektiv. Den næste årti står derimod i individualismens tegn. I 80'erne udgiver Mørch bl.a. Aftenstjernen (1982) og Morgengaven (1984), hvor hun skildrer henholdsvis livets sidste fase (inspireret af omsorgen for sin døende mor) og det problematiske forhold mellem kunstnerlivet og kærlighedslivet, som fører til parforholdets opløsning (med inspiration hentet igen fra forfatterens eget liv - forfaldet af hendes og Troels Triers ægteskab). I 90'erne udgiver hun to brevromaner (en af dem sammen med datteren Sara) og markerer dermed endnu et (denne gang formelt) brud i sit forfatterskab. Alle Mørchs bøger bærer selvbiografiske præg, de er alle realistiske samt vidner om forfatterens politiske og sociale engagement. Med denne korte litteraturhistoriske gennemgang af Mørchs forfatterskab som udgangspunkt vil jeg konstatere, at hendes rejsebøger danner en adskilt kategori ikke bare med henblik på det genremæssige aspekt, men også hvad stilen og forfatter-/fortællerposition angår. Det er ligeledes værd at understrege, at Mørch har illustreret alle sine rejsebøger (med tegninger, linotryk og raderinger), og begge dimensionerne - den sproglige og den visuelle - bør læses og fortolkes parallelt. De fungerer nemlig som pejlinger i den samme retning: de bærer impressionistiske præg og "bevæger sig i et grænseland mellem modernisme og realisme, præget af sensibilitet og fremmedfølelse", som Anne Brigitte Richard (2003) har udtrykt det.

I det følgende analyserer jeg Mørchs tre rejsebøger, som ikke har været genstand for forskning indtil $\mathrm{nu}^{3}, \mathrm{og}$, som jeg tidligere har nævnt, skiller de sig

\footnotetext{
${ }^{2}$ Romanen er blevet oversat til over tyve sprog samt filmatiseret af Astrid Henning-Jensen i 1978.
} 
markant ud i forhold til forfatterens $\varnothing v$ vrige bøger. Jeg vil også diskutere spørgsmålet om deres placering inden for rejsebogsgenren, samt forfatterens måde at repræsentere de fremmede himmelstrøg på. Diskussionen tager udgangspunkt i genrens poetologiske kendetegn på den ene side og det imagologiske begreb om repræsentation samt de narrative strategier, som forfatteren benytter sig af på den anden side.

\section{DET POETOLOGISKE}

Som nævnt før, kan der laves endnu en opdeling af Dea Trier Mørchs forfatterskab - stilmæssigt. Mens den dominerende stilmæssige modus i hendes romaner udgøres af simpel skrivemåde, dvs. ikke stærkt metaforiseret og næsten uden andet sprogligt pynt, virker hendes rejsebøger meget mere kunstnerisk bearbejdede, med næsten impressionistisk stil, hvor stemninger og indtryk fanges i et melankolsk virkende narrativ. Erik Vagn Jensen (1985:108f.) definerer forskellen således:

Begge disse to „rejsebøger” [Sorgmunter socialisme og Polen, S.I.S.] er skrevet helt anderledes end det senere forfatterskab. Et mylder af associationer, lange dansende sætninger, romantisk historieskrivning.

Mørch bestemte sig til at nedfalde sine rejseindtryk på skrift inden for en bestemt genre og henviste dermed til en lang tradition for rejselitteratur med sine egne indre genremæssige regler samt psykologiske, sociale, politiske og kulturelle kontekster, som er med til at påvirke teksternes udlægning (vide Thomson 2011; Moroz 2013). Derfor fokuserer jeg i det følgende på Mørchs rejsebøger med henblik på genrens tradition og normer.

Det grundlæggende spørgsmål om, hvad en rejsebog er, kan hverken besvares nemt eller entydigt. Trods sin lange tradition (siden antikken) har rejselitteraturen hverken fået et stabilt begrebsmæssigt instrumentarium eller en afklaret genremæssig status. Når der tales om tekster, hvor rejsen udgør det kompositoriske princip, er hovedmotivet eller giver anledning til at fortælle en historie eller komme med essayistiske overvejelser, er der flere betegnelser, der tages i brug såsom: rejselitteratur, rejsebog, rejseskildring, rejseberetning, rejseroman, rejsebreve. Rejselitteraturen, hvis man bestemmer sig til at bruge det som et overordnet samlebegreb, som undertegnede gør, omfatter en række tekster, som tilhører både prosaiske, lyriske og dramatiske genrer, som er spændt mellem roman, dokumentarisk prosa, autobiografi og essay ${ }^{4}$, og dermed

\footnotetext{
${ }^{3}$ Der findes kun enkelte kommentarer til Mørchs rejsebøger i forfatterportrætter og analyser af hendes øvrige værker, som hos Gunhild Agger (1981) og Erik Vagn Jensen (1985).

${ }^{4} \mathrm{Se}$ fx de nyeste forsøg på at beskrive og definere rejselitteraturen hos Carl Thomson (2011) eller Grzegorz Moroz (2013).
} 
udgør en "tågeagtig", efemerisk enhed, som er svær at afgrænse, og som både kan være meget inkluderende - (næsten) altomfattende - og meget snævert forstået. Det er derfor man finder definitioner som hos Arne Melberg (2005:11, 12):

En diffus genre som inte har någon självklar plats i litteraturen.", "(...) ett fält av möjligheter, där varje författare skapar sin egen reselitterära variant med hjelp av det kontrakt han/hon tar i bruk för att koordinera information och fiktion.

eller Lars Handesten (2004:75):

(...) en hybridgenre, der med fortælleren som garant for autenticiteten og som omdrejningspunkt, balancerer mellem det subjektive og objektive, mellem fantasi og fakta, mellem erindring og samtidsbeskrivelse, mellem oplevelse og refleksion.

- ved siden af de mere restriktive som hos Paul Fussell (1980), Mary B. Campbell (1988) eller Jan Borm (2004) $)^{5}$, som begrænser dette felt til de ikke fiktive former og dermed modstiller rejselitteratur og roman. Den eneste afgrænsning, som synes at stå fast, er mellem de fiktive (som fx rejseroman eller utopi) og de ikke fiktive former (som rapport, beretning) for rejselitteratur, selvom det langtfra er uproblematisk (vide grænser mellem fakta og fiktion, som ikke kan drages entydigt, hvor det referentielle pagt brydes eller hvor (med Poul Behrendts betegnelse, Behrendt 2006) dobbeltkontrakten indgås).

Dea Trier Mørchs rejsebøger falder under den sidstnævnte kategori - der er tale om autentiske rejser foretaget af forfatteren, som samtidig er bøgernes fortæller og protagonist, samt om et ikke fiktivt narrativ. Det sidstnævnte, dvs. teksternes autenticitet, burde dog ikke forstås meget stringent. Som flere forskere påpeger (se fx Holland \& Huggan 1998; Thomson 2011), kombineres det ikke fiktive (den autentiske rejse) ofte med litterære, fiktive fortælleteknikker i rejselitteraturen ${ }^{6}$. Mørchs rejsebøger kan betegnes som rejseskildringer eller rejseberetninger, som Margareta Petersson (1988:12-24) definerer ved hjælp af følgende træk: (a) forfatteren er identisk med fortælleren, (b) det er den rumlige dimension (og ikke den tidsmæssige som fx i en dagbog), der spiller afgørende rolle i tekstens komposition, (c) rejsen udgør "den tematiska variabeln" i teksten, dvs. den skal være til stede, men behøver dog ikke dominere tekstens tematik, (d) "den tvåledade strukturen", dvs. det at være spændt mellem to modale poler: den deskriptive og den berettende, hvis man bruger Gerard Genettes termer (efter Petersson, ibid.) eller "den scientistiske" og "den indtryksmæssige" (Korwin-Piotrowska 2001:161ff.) - altså mellem det,

\footnotetext{
${ }^{5}$ Jf. diskussionen hos Thomson (2011:15ff).

${ }^{6}$ Se rejselitteraturens tidligere nævnte inhærente træk - balancegangen mellem det rigtige, det troværdige, det påviselige og det imaginære, det opfundne, det løgnagtige.
} 
der på den ene side bygger på den rejsendes (og samtidig fortællerens) (forhånds-)viden og på den anden side det, der udspringer fra hans eller hendes sanselige indtryk, er hans eller hendes reaktion på det, han eller hun sanser, fornemmer og tænker. I den deskriptive får man en mosaik af fakta, som ikke er så kohærent som i den berettende, hvor det er forfatterens/fortællerens bevidsthed, som udgør den stærk integrerende funktion i forhold til teksten, hvor de retrospektive elementer er overvejende og hvor litterære teknikker oftere tages i brug (se Petersson 1988:16). Peterssons forslag bør opfattes som vejledende ( $\mathrm{g}$ dermed ikke som en restriktiv formel), for som mange andre udlægninger $\mathrm{i}$ forsøget på at afgrænse rejsegenren er det en sandhed med modifikationer.

Når man betragter Mørchs rejsebøger ude fra de ovennævnte kriterier, kan man konstatere, at de i hvert fald fører de første tre af dem ud i livet. Mørch har foretaget autentiske rejser til Polen, Sovjetunionen og USA, som bl.a. kan dokumenteres med det materiale, som indgår i hendes arkiv ${ }^{7}$. De er alle tre skrevet som førstepersonnarrativer, hvor forfatteren samtidig er deres fortæller. Mørch anvender dog også teknikker, som gør, at påstanden om, at forfatteren og fortælleren er den samme person, delvis mister sin gyldighed. Det er når der kommer perspektivskifte $-\mathrm{fx}$ når der indføres dialoger eller når direkte tale flettes ind i teksten (fx når det er Esther, der fortæller sin livshistorie i Polen, Mørch 1970:91ff.). Nogle andre gange skifter fortælleperspektivet fra det individuelle (1. person singularis) til det kollektive (1. person pluralis). Mørch tager det kollektive vi-perspektiv i brug, og det sker, når fællesskabsfølelsen tilstræbes, når der direkte udtrykkes det, som tidligere i artiklen blev defineret som forfatterens vilje til at blive en del af den oplevede virkelighed, hendes søgen efter en menneskelig, men også ideologisk fællesnævner - et forsøg på at ophæve de almindelige grænser: etniske, mellem lande, religioner og levemåder. Mørch benytter sig også af en teknik, som med et begreb hentet fra postkoloniale studier kaldes for voicing - den går ud på at flette flere (indfødte) stemmer ind i narrativet, som igen gør at teksten fremstår som mere "objektiv" Flerstemmigheden bruges også til at understrege, at forfatteren er et (troværdigt) øjenvidne - hun har været på stedet og er kommet i kontakt med de indfødte; den bliver altså brugt som en del af tektens konstruktion, som en teknik, der viser tilbage til det moderne "epistemologiske dekorum" (se begrebet hos Thomson 2011:72), dvs. tekstens elementer, der understreger dens troværdighed og opbygger dens autoritet.

${ }^{7}$ Dermed mener jeg arkivet på Det Kongelige Bibliotek i København, hvor man efter forfatterens $\mathrm{d} \varnothing \mathrm{d}$ har afleveret hendes notater, tekster, artikler, avisudklip samt dokumenter forbundet med hendes studieophold i Polen og i Sovjetunionen. Materialerne er klausureret frem til 2022, men det lykkedes undertegnede at få tilladelse til at bruge dem nu.

${ }^{8}$ Vedr. voicing som en narrativ strategi, som tjener det formål at give stemmen til "the subaltern" se Thisted (2011:93f.). 
Dominansen af den rumlige dimension, der udpegedes af Petersson som den anden af rejseskildringernes genremæssige kendetegn, kan fx tydeligt ses $\mathrm{i}$ Polen, hvis komposition ikke nøje følger det tidsmæssige princip. Bogen begynder nemlig ikke med forfatterens-fortællerens indrejse i landet eller hendes første indtryk, men med beskrivelsen af besøget i landsbyen Koszki (kapitlet "Hos de hviderussiske bønder"), hvor hun måtte have været senere under sit ophold i Polen (jf. arkivmaterialerne, se fodnote 7). Den indledende del danner derimod pendant til et kapitel i slutningen af bogen ('I Poreba Wielka"), og begge to udgør de en kompositorisk ramme, hvor passager med beskrivelser af by- og studenterlivet indrammes i scener fra det "oprindelige" og "naturlige" Polen. Dermed kreerer Mørch værkets eget ideologiske rum, hvor den underordnede tidsmæssige akse åbner for nye udlægninger. Tekstens struktur afspejler nemlig måden at repræsentere Polen på - set med den danske studerendes $\varnothing j n e$ er landet fuldt af liv, dynamisk og ungt, men forfatteren henviser også til den danske (og vesteuropæiske) diskurs om Polen, som tilbagestående, provinsiel og tidløs (jf. Wolff 1994).

Denne forståelse af rum som strukturelement i teksten samt dens emne (det at bevæge sig gennem rum) er ikke den eneste, der gør sig gældende i Mørchs rejsebøger. Rummet - eller mangel på samme (på frirummet) på det individuelle, intime plan - udgør ligeledes et af de store emner i debutbogen Sorgmunter socialisme. Det påtvungne samvær, den fysiske tæthed på andre i alle slags hverdagssituationer præsenteres ideologisk (fra det indre - sovjetiske perspektiv) som et af de redskaber, der er med til at opdrage folk til sociale væsener under overskriftet om socialistisk fællesskab og hensynstagen til andre:

Overalt tvinges man ind i en fysisk men ikke sensuelt samvær med andre: I de bristefærdige lejligheder, i køerne foran butikkerne, i trolleybusserne og på studenterkollegierne. Der er intet sted man kan være upåagtet, og jeg opnår ikke at komme i svingning. Den yderste brod af bitterheden brækkes af. Jeg bliver social og mere positiv. Jeg må jo handle mod andre som jeg ønsker de skal handle mod mig. Altså betænksomhed. Og betænksomhed - det siger sig selv - forbrænder så stor en del af ens tankevirksomhed. (Mørch 1968:31)

I bogen understreges ellers kontrasten mellem det vidt udstrakte, arealmæssigt enorme Sovjetunion og den trængsel, som karakteriserer de mellemmenneskelige relationer. Forfatteren-fortælleren, som tilstræber samhørighedsforhold og fælleskab, det at være en del af kollektivet, bliver paradoksalt nok til et fremmed element, ikke kun i kraft af sin udenlandske status, men også på grund af en indre modstand, som spirer i hende - modstand mod at forsvinde i den grå masse. Det trange fysiske rum modarbejder hendes $\emptyset$ nske om at blive en del af den besøgte verden på mindst to måder: på den ene side bliver det umuligt for den rejsende at opfatte helheden, perspektivet forbliver fragmentarisk, på den anden - det koncentrerede menneskemylder lammer hende og er i vejen for, at hun kan "komme i svingning". 
Rummets betydning i Mørchs sidste rejsebog (Da jeg opdagede Amerika) tydeliggøres med adskillige tegninger, som bogen er illustreret med. Mange af dem er kort over enkelte områder i New York samt afbildninger af de enkelte newyorkske bygninger og afkroge (men også af San Francisco og andre steder i USA). Målet bliver at "se det hele selv!" (Mørch 1986:10), begærligt at indsamle alle mulige indtryk, gøre byen til sit, bemægtige sig den, hjemliggøre og tæmme den. Dette sker ved at forfatteren-fortælleren bevæger sig fysisk i den, går til fods, finder vej og går vildt, og ikke efter det intellektuelle modul, hvor den rejsende bevæger sig gennem et hav af tekster om stedet. Det er det håndgribelige og samtidig det transcendentale, der udgør den erkendelsesmæssige akse i rummets tilegnelse og begribelse:

$\mathrm{Nu}$ ved jeg det: Manhattan er otte timer lang - én time bred og otte timer lang. (Mørch 1986:109).

Jeg prøver til at få Manhattan til at hænge sammen. (ibidem:135).

Dermed bliver Mørch til en moderne byvandrer i den baudelaireske facon hun følger i den klassiske flâneurs $^{9}$ fodspor. Hun giver sig tid til at opleve, sanse, se og høre i et tempo, der ikke er på højde med hendes samtids hastighed. Og hun giver sig ret til at se sig selv som pioner, som hun formulerer det på bogens sidste side: "Det vi oplever i dette nu - er aldrig oplevet før." (Mørch, 1986:215). Rummet i hendes sidste rejsebog bliver dermed til en åben og udfordrende størrelse, til en uudslukkelig inspirationskilde, en bundløs beholder fyldt med forskelligartede indtryk.

Rejsen bliver brugt som en direkte årsag til opståen af Mørchs rejsebøger; den fungerer som bøgernes tematiske variabel (for at komme tilbage til Peterssons kriterier), men ikke nødvendigvis som deres hovedemne. Sagt med andre ord er det ikke det at rejse, der udgør hovedemnet - rejsen er frem for alt bøgernes strukturgivende element - i kraft af de skiftende steder og landskaber, der giver anledning til indsamlingen af nye iagttagelser og indtryk. I debutbogen (Sorgmunter socialisme) samt i den næste bog (Polen) er forfatteren-fortælleren på et længerevarende ophold som stipendiat $\mathrm{i}$ henholdsvis Sovjetunionen og Polen, men hendes beretning er ikke begrænset til de byer, hvor hun studerede (Leningrad, Warszawa og Krakow). Som resultat får man, som fx i Polen, en broget mosaik af storbylivet samt livet ude på landet, af livet i hovedstaden samt i provinsen, livet blandt kunstnere, studerende, men også blandt almindelige polakker på gaden og polske bønder - et billede af både "centret" og "periferien". Rejsen foretages således ikke kun i geografisk forstand, men den vedrører også dimensioner som fortid, forskellige miljøer samt forfatterens

\footnotetext{
${ }^{9}$ Vedrørende begrebet flâneur se Benjamin (1996) og Zeidler-Janiszewska (1999).
} 
indre rejse - hendes forsøg på at blive bedre kunstner, men også på at komme tættere på det usminkede, autentiske liv, som hun mener findes i Polen, som tilsyneladende ikke er blevet spoleret af den kapitalistiske ånd som i hendes hjemland. Som forfatteren selv konkluderer $i$ et af interviewerne givet til en polsk avis, er Østeuropa det sted, som „tilbyder et rigt forskningsmateriale til enhver, der søger efter viden om de basale følelser, som styrer mennesker" (min fremhævelse, S.I.S. $)^{10}$. Og det er netop denne menneskelige dimension, som står i centrum for hendes skildringer af Sovjetunionen og Polen.

Med henblik på det sidste af Peterssons kriterier, dvs. den konstante balancegang mellem det scientistiske og det indtryksmæssige, kan jeg med udgangspunkt i det, jeg indtil nu har fremlagt, konstatere, at Mørchs rejsebøger i højere grad hælder mod det sanselige og berettende end det intellektuelle og beskrivende. Styrken i hendes fremstilling ligger således, som Gunhild Agger (1981:105) udtrykker det, "i iagttagelsen, erindringen og sammenligningen fremfor i det mere dybtgående, komplekse og analyserende." Dette ses både i sproget - i den ligefremme stil med korte sætninger og uden unødvendig pynt (som dog ikke er fri for retoriske greb), samt i den impressionistiske måde at repræsentere virkeligheden på. Strukturen af Mørchs rejsebøger kan bedst beskrives med ordene heterogen eller hybrid, som ofte tilskrives rejsegenren som et af dens vigtigste karaktertræk (se fx Melberg 2005, Thomson 2011 o.a.). De indeholder elementer af prosaisk beskrivelse, fortælling (med dialoger som dynamiserende elementer, men også emanationer af voicing), men også poetiske passager - struktureret som digte, eller i form af prosalyrik. Sidst men ikke mindst benytter forfatteren sig af intermedialiteten, idet hun gør hyppig brug af egne tegninger, raderinger og linosnit. Hun benytter sig af kunstarternes søskendeforhold for at intensivere helhedsudtrykket - det visuelle spiller sammen med det tekstuelle, de supplerer hinanden i et overordnet projekt, som går ud på at fange en så bred vifte af stemninger og øjeblikke som muligt ${ }^{11}$.

\section{REPRÆSENTATION OG DE NARRATIVE STRATEGIER}

Begrebet repræsentation fortolker jeg med udgangspunkt i de imagologiske studiers forståelse af image/billede, påvirket af inspirationen hentet fra dekonstruktionisme. Ann Rigney (2007:415) definerer det som forholdet mellem teksten og virkeligheden, forholdet, der ytrer sig i de diskursivt formede images - eller rettere "ways of constructing and directing our view of the world with the help of language". De billeder af den fremmede virkelighed, der

${ }^{10}$ Fra et interwiew med forfatteren, som kunne læses i avisen Dziennik Battycki, 14-15. 06.1970, med titlen ,,>>Manifest komunistyczny $<<$ z ... helikopterami” [ $>>$ Det Kommunistiske Manifest $<<$ med... helikoptere].

${ }^{11}$ De interatielle forhold i Mørchs tekster bliver ikke diskuteret yderligere i foreliggende bidrag pga. dets begrænsede omfang. 
konstrueres af den rejsende forfatter, bliver til ved hjælp af litterære midler og bestemte narrative strategier tages i brug. Der er derfor rettere tale om et bevidst og gennemarbejdet litterært projekt (som dog ikke udelukker det ubevidstes og spontanes indflydelse) og ikke om en simpel mimestisk gengivelse af det, som den rejsende ser og registrerer. Mørchs overordnede projekt som rejsebogsforfatter kan med udgangspunkt i hendes rejsebøger beskrives med adjektiver som iagttagende, sansende og ikke intellektuelle. Og hendes narrative strategier har jeg valgt at sammenfatte under overskrifterne: det empiriske, det impressionistiske, det flâneuragtige, det sanselige, det eksistentielle og det (skjult) kritiske. Det er i forhold til de ovennævnte kategorier som referencepunkter jeg analyserer Mørchs rejsebøger i det nedenstående.

Den overvejende berettende modul at repræsentere virkeligheden på i Mørchs rejsebøger gør, at man får et billede af forfatteren-fortælleren som en "naiv" rejsende, altså én, der med et barns uskyldighed (og uvidenhed) ser og prøver at sætte ord på den fremmede virkelighed. Mørch benytter sig af en "registrerende" teknik, når hun med korte og konstaterende sætninger, eller blot enkelte ord, som indgår i mere omfattende passager, opstiller de enkelte ting, fænomener og oplevelser som på en huskeliste (eller som et barn, der peger med fingeren og undrer sig over verdens små mirakler). Den glimtagtige måde at skildre Amerika på understreges af talrige hurtiglavede tegninger, som viser de enkelte øjeblikke, mennesker og steder, og giver hele bogen en kalejdoskopisk form. Mørch skriver:

\author{
Legepladser. \\ Sportspladser. \\ Skulpturer og monumenter. \\ Museer og restauranter og små cafeer. (Mørch 1986:17) \\ Herald Square. Trafikknudepunkt. Skyskrabere. Utroligt flotte. (ibidem:94) \\ I et vindue en kikkert. \\ En buket forglemmigej. \\ Feminine mænd i bløde sko. Veninder arm i arm. Zigeunere og transvestitter og svenskere. \\ Bambinier i klapvogn. En zeppeliner i slow-motion på himlen. En sølvdråbe. En dråbe af \\ sølv i den himmel. (ibidem:126)
}

Teknikken, der går ud på kun at sætte punkter ved siden af hinanden uden at indramme dem med nogle tydelige konturer vækker associationer til de franske impressionisters stil. Et hav af farverige prikker går op i en højere enhed i seerens/læserens øjne og hjerne - det er dermed han eller hun, der får til opgave at svare på de spørgsmål, som teksten rejser, og der har "ansvaret" for at få de enkelte elementer til at hænge sammen. Mørchs repræsentationsstategi kan således på den ene side betegnes som impressionistisk og på den anden side er det det sensuelle, der står tydeligst frem. Det er ikke mindst tilfældet i Polen, 
som hun beskriver gennem sanser og med enkelte indtryk og situationer: med farver (hvis bagrund udgøres af de dominerende grå toner) og fremmedartede lugte, som i det nedenstående citat:

Når jeg lukker øjnene og tænker på Polen, er det altid disse lugte, der kommer mig imøde. Lugte, jeg ikke kender noget andet sted fra. En lugt af klor og kalk, af kridt og puds, en lugt af sæber der udtørrer slimhinderne. En duft af friske ugeblade, der smitter af, af gnister, af groft papir, der let går itu.

En lugt af gamle varmeapparater, hvor det samme vand i årtier har været indelukket i det samme system. Vintertøj, filt, løs tobak i cigaretterne. Græsarter, rødbedesuppe. Og lugten af mennesker der ikke i lang tid har været vasket - den ramme tætte stank af kroppe i en biograf når lyset slukkes. Af nakker bag skjorterne, af armhuler, munde - som rovdyrburet i en zoologisk have. (Mørch 1970:62)

Forfatteren kan dog i den samme forbindelse karakteriseres som en følsom rejsende (jf. Rifbjergs anmeldelse af Polen, 1970) - følsom i den sterneske facon (se Sterne 1960). Som en del af det følsomme paradigme indgår den sterneske protagonist Yoricks søgen efter det naturlige, i takt med den rousseauske idé om civilisationens og kulturens negative indflydelse på individer og lovprisning af naturtilstanden (Rousseau 1956). I Mørchs tilfælde er det søgen efter det autentiske, efter det melankolsk opfattede autentiske fællesskab, men også en rejse i selverkendelses og selvrealiserings tegn, der gør sig gældende. Hendes rejser synes ikke at have et fastsat mål (selvom dette ikke helt stemmer overens med de faktiske - biografiske - forhold), hun synes at rejse for selve rejsens skyld. Det er ligeledes forfatteren-fortælleren, som udgør omdrejningspunktet - det er hendes optik, sindstilstande, associationer og oplevelser, hvorigennem den fremmede virkelighed bliver formidlet. "[I]ntet er nødvendigere i en Reise end en Reisende" - den paradigmatiske danske følsomme rejsende Jens Baggesens (1986:15) ord står således fortsat deres prøve med henblik på rejsegenren og ikke mindst Mørchs rejsebøger.

Empirien kan karakteriseres som den dominerende erkendelsesmæssige og narrative - strategi i Mørch rejsebøger, men det er ikke ensbetydende med, at "rejsen i biblioteket" mangler - altså, at den intertekstuelle dimension er fraværende. Transtekstualiteten, som Gérard Genette (2014) har kaldt fænomenet, kan ses både eksplicit og implicit i bøgerne. I Polen ses den fx i direkte citater fra bogen skrevet af den kanoniske polensrejsende Georg Brandes og hans værk Indtryk fra Polen (1888) samt gennem den måde landet bliver anskuet på - altså gennem de fortolkelseskategorier, som blev udstukket af Brandes og som har rod i en bredere europæisk kulturkontekst (samt dens forenklede billeder af andre nationer), såsom den polske gæstfrihed eller den polske splittethed og dobbeltnatur (se Schab 2008, 2009). Det iøjnefaldende er også et hyppigt brug af kristne motiver og symboler i rejsebøgerne. Kommunisten Mørch benytter sig hyppigt af de bibelske topoi, når hun som forfatter skal sætte ord på de hverdagsbilleder, hun er vidne til under sine rejser. 
Således bliver rulletrapperne i Leningrads metro til en jakobsstige, en sovende mand fra toget bliver beskrevet som Jesus ("Om et par timer skal han kaste stenen af sig og genopstå.”, Mørch 1968:111). På omslaget af Polen bruges billedet af Kristus på korset, som kan læses som en antydning til polakkernes selvforståelse som nationernes Kristus, men også som en slags axis mundi i polakkernes verdens- og livsanskuelse. Der henvises til Bibelen samt citeres fra den uden at angive kilden som fx i Polen). Vejen gennem Harlem bliver til en passionsvej (Mørch 1986:160), månen - til en "oblat på himlens bagtæppe" (ibidem:162).

Mørch udtrykker en eksistentiel, men samtidig meget konkret, "jordbunden" usikkerhed, uro og tvivl i sine rejsebøger. Hun synes at rejse for at stille sine behov for samhørigheden, trygheden, fællesskabet, for at se, hvordan man kan være lykkelig under fremmede himmelstrøg, og dermed prøver at finde svar på almenmenneskelige eksistentielle spørgsmål. Den ideologiske kontekst for hendes rejser til Sovjetunionen og Polen er, at hun rejser væk fra sit hjemland, som hun er kritisk indstillet over for - som over for et sted, hvor den kapitalistiske tankegang vinder indpas og fortrænger den mellemenneskelige solidaritet. Rejserne til Sovjetunionen og til Polen kan derfor ses som rejser mod det forjættede land, men Mørch giver på ingen måde den slags endimensionelle svar. Trods den unægtelige sympati over for begge lande, kommer der flere sprækker i billedet, når det tilsyneladende paradis på jorden repræsenteres. Sanseligheden og seksualiteten fortrænges, ensomhedsfølelsen, sygdommen, nedtryktheden er officielt fraværende i kollektivets land: "Man kan ikke være ensom i kollektivet, heller ikke syg, og under ingen omstændigheder fortvivlet." (Mørch 1968:68). Lykken manifesteres i Sovjetunionen gennem en erstatning - "lykkebringende" billetter med en bestemt talkombination, som de overtroiske russere samler på. Ellers kan lykken få en rå og upoleret smag, som i fortællerens øjne virker håndgribelig, autentisk og tilgængelig for de jævne mennesker, men som dog samtidig har en bitter bismag:

Jeg går ud i køkkenet og laver én af disse dyre, grumsede socialistiske kopper kaffe der egentlig slet ikke er noget nydelsesmiddel, og skærer et stykke sovjetisk ost med en smag af absolut ingenting, finder min avis frem, læner mig tilbage i en blakket, polstret stol hvis armlæn er faldet halvt ned mod gulvet og føler, at dette er lykken i Rusland - dette har jeg længtes efter siden jeg kom! (Mørch 1968:78)

Forfatteren er således meget diskret med sin kritik vedrørende landet, for "[f]ørst og fremmest gælder det om at sige noget positivt, noget der for guds skyld ikke kan skade Sovjetunionen..." (Mørch 1968:121), som hun ironisk bemærker. Det bitre element af sammensætningen "sorg-munter": beklemtheden, den manglende tryghedsfølelse, ensomheden og fremmedgørelsen kommer til overfladen gennem sprækker i fortællingen - 
antydninger, små bemærkninger, hverdagsbilleder (som fx værelseskammeratens Natasja indlæggelser, den russiske kollegas (med øgenavnet Voice of America) depression, en blotter på gaden, en fuld mand på gaden med en lille datter). Mørch benytter sig også af den parallelle virkelighed i form af drømmesyn, for at give udtryk for det, der ligger skjult under overfladen og bliver fortrængt fra den officielle diskurs. Som fx i drømmen om fangelejre i Sibirien, hvor hun bliver forhørt af en streng dommer (ibidem:5153). Forsoningen med landet (Sovjetunionen) kommer først til sidst, hvor hun opnår "en dyb fred" (ibidem:154), staten tager hende imod, viser hende "en udstrakt godhed" (ibidem:155), men det sker helt på Sovjetunionens præmisser - hun er fysisk og psykisk i dens magt. Den sidste scene i bogen, hvor forfatteren eksplicit udtrykker disse tanker er, når hun er indlagt på et hospital magtesløs og i en dvaleagtig tilstand, og hvor angsten kommer "krybende langt borte fra, sort og mægtig" (ibidem), kan derfor læses parabolisk og symbolsk. En lignende form for ambivalens (det følelsesmæssigt at bevæge sig mellem det sørgelige og det muntre) kommer til syne i hendes anden rejsebog. Den sjælerejse, som forfatteren begiver sig på, er ligesom Sovjetrejsen psykisk og fysisk udfordrende; den rejsende skal altid være på vagt og konfronteres med ustadighed, uforudsigelighed og mangel på klare regler, spændes mellem det fortryllende og det skuffende:

I Polen ved man ikke, hvor meget man kan tillade sig. Man balancerer på kanten, men kan let falde baglæns i kløften, mens andre står oppe på kanten med hænderne på knæerne og ser kede ud af det - hvis de da ikke netop slår en høj latter op. Men i øvrigt havde jeg stadig den opfattelse, at jeg havde sluttet forbund med Polen, og at dette forbund bestod, trods alt. (Mørch 1970:180).

De sidste ord i citatet viser ellers tilbage til Brandes' Indtryk fra Polen og hans "malgré tout", som fungerer som en kompositorisk ramme (er mottoet for Indtryk fra Polen og sidste ord i bogen) og kommentar til den ambivalens og kontrasttænkning, der er en af de mest centrale bestanddele af den danske Polen-diskurs (se Schab 2008, 2009). I Mørchs sidste rejsebog - fra Amerika kommer samme slags subtile samfundskritik til udtryk. De tre rejsebøger taget $\mathrm{i}$ betragtning kan Mørchs rejse - den fysiske, men også i en vis grad ideologiske - beskrives som en rejse fra det forjættede land (Sovjetunionen) over overgangs- og ambivalenslandet mellem Øst og Vest (Polen) til kapitalismens fødested, det for en kommunist (som Mørch jo var i en periode) suspekte sted associeret med social ulighed og undertrykkelse. Som selve titlen på bogen ( $D a$ jeg opdagede Amerika) dog antyder, er der tale om en "opdagelse", der sker altså et erkendelsesmæssigt gennembrud i opfattelsen af landet - Amerika får et menneskeligt ansigt. Den empatiske rejsende er som i tidligere (rejse-)bøger solidarisk med almindelige mennesker, specielt dem, der lider under en eller anden form for undertrykkelse - hun får фje på kvindernes situation (den 
tabuiserede prævention, fødsler), tiggere, de fattige sorte i Harlem, de puertoricanske indvandrere udnyttet som billig arbejdskraft og ikke mindst kunstnere, som har svært ved at få økonomien til at løbe rundt.

\section{SAMMENFATNING OG PERSPEKTIVERING}

Mørchs rejsebøger ligger i forlængelse af en tradition inden for rejsebogsgenren, som gjorde sig gældende med de følsomme rejsendes fremmarch efter det sterneske forbillede (Jens Baggesen i Danmark [1792-93], 1986). Forfatteren og kunstneren er en empatisk rejsende med en social sensibilitet og med en åbenhed og respekt over for den anden i hans/hendes kulturelle anderledeshed. Hendes overordnede fortælleteknik tager sanserne i brug, for gennem dem (synet, lugtesansen, hørelsen, følesansen og smagen transformeret til sproglige billeder) at formidle et flerdimensionelt billede af den fremmede virkelighed. Mørch bevæger sig i grænsezonen mellem det reportageagtige, det dagbogsagtige, det fortællende og det poetiske (hvor det sidstnævnte markeres bl.a. med tekstens organisering i strofer, som fx i $D a$ jeg..., s. 14, 204). Teksternes hybriditet understreges også af de raderinger, linosnit og tegninger, som ikke blot er til pynt, men som spiller sammen med teksten og fremstår som en kommentar (konkret eller parabolisk, symbolsk) til det, der beskrives.

Men Mørchs rejser har også en eksistentiel dimension - de er forfatterens vej til en bedre selvforståelse; hendes forestillinger, forventninger og idealer bliver sat på prøve i konfrontationen med virkeligheden. Hun kan også siges at begive sig ud på en melankolsk rejse - i søgen efter det, hun savner i Danmark (socialistisk social retfærdighed, solidarisk fælleskab og broderskab, det at være tæt på livets ægte værdier versus den ureflekterede konsumptionistiske tilgang til tilværelsen derhjemme) eller direkte har mistet (hvor hun rejser til Amerika i den på dette tidspunkt afdøde mors fodspor). Glimtvis giver rejsen en følelse af at "se sig selv", være hjemme, være en del af et større transcendentale fællesskab, som forfatteren fx opdager under besøget på et museum i New York:

Jeg tænker tit over, hvad hjem betyder.

Jeg føler, jeg kommer hjem til Museum of Modern Art - kaldet MOMA - i New York!

(...)

Denne følelse af at komme hjem til Museum of Modern Art - får mig til at tænke på de jøder, der første gang står foran grædemuren i Jerusalem. I deres sorte tøj ser de lige ind i den murs sten. Og inde i stenen ser de sig selv - gentaget og gentaget og gentaget. (Mørch 1986:20, 22)

Mørch bekender sin tilslutning til det internationale kunstnerfællesskab, hentyder til et religiøst fællesskab - jøderne - som hun gennem sin jødiske 
afstamning kan føle sig en del af, men frem for alt (gennem de sidste tre ord $\mathrm{i}$ citatet) formulerer den eksistentielle situation, som driver individer ud på rejse bekræftelsen af det rejsende subjekts jeg, muligheden for at "se sig selv" i det fremmedes spejl, udfordringen af sig selv under forskellige omstændigheder, som dog har den konstant, at de opleves gennem det samme individs intellektuelle og følelsesmæssige præmisser. Gentagelsen af det rejsende subjekts fremmedgørelse og konfrontation med sig selv - gentagelsen, som er vejen til selverkendelsen - kan derfor opfattes som et af kodeordene i Mørchs rejsebøger.

\section{LITTERTURLISTE:}

Agger, Gunhild. 1981 (1980-82). Dea Trier Mørch. [i:] Brostrøm, Torben \& Mette Winge (red.). Danske digtere $i$ det 20. århundrede, t. V, København: G.E.C. Gad, s. $96-105$.

Baggesen, Jens. (1792-93) 1986. Labyrinten eller Reise giennem Tydskland, Schweitz og Frankerig. København: Gyldendal.

Behrendt, Poul. 2006. Dobbeltkontrakten: en aestetisk nydannelse. København: Gyldendal.

Benjamin, Walter. 1996. Paryż - stolica XIX wieku (Paris, die Hauptstadt des XIX. Jahrhunderts, 1935) og Paryż II Cesarstwa według Baudelaire'a (Das Paris des Second Empire bei Baudelaire, 1938). [i:] Idem. (udvalgt og bearbejdet af Hubert Orłowski). Aniot historii. Eseje, szkice, fragmenty. Poznań: Wydawnictwo Poznańskie, s. 317-334; 335-388.

Borm, Jan. 2004. Defining Travel: On the Travel Book, Travel Writing and Terminology. [i:] Hooper, Glenn \& Tim Youngs (red.). Perspectives on Travel Writing (= Studies in European Cultural Transition, vol. 19). Ashgate, s. 13-26.

Campbell, Mary B. 1988. The Witness and the Other World. Exotic European Travel Writing, 400-1600. Ithaca and London: Cornell University Press.

Fussell, Paul. 1980. Abroad: British Literary Traveling Between the Wars. New York: Oxford University Press.

Genette, Gérard. 2014. Palimpsesty. Literatura drugiego stopnia. (overs. af Tomasz Stróżyński, Aleksander Milecki). Gdańsk: słowo/obraz/terytoria.

Handesten, Lars. 2004. Rejsebogen. En grænseoverskridende genre. [i:] Teilmann, Katja (red.). Genrer på kryds og tvars. Odense: Syddansk Universitetsforlag, ss. 71-86.

Holland, Patrick \& Graham Huggan. 2000. Tourist with Typewriters. Critical Reflektion on Contemporary Travel Writing. Michigan: The University of Michigan Press.

Jensen, Erik Vagn. 1985. Sorgmunter socialisme. [i:] Wamberg, Bodil (red.). Blixen, Brøgger og andre danske damer. (Viborg): Forlaget Centrum, s. 103-118.

Jørgensen, John Chr. (red.). 2001. Dansk forfatterleksikon. Biografier. København: Rosinante (Mørch, Dea Trier, 320f., Vibeke Blaksteen)

Korwin-Piotrowska, Dorota. 2001. Problemy poetyki opisu prozatorskiego. Kraków: Universitas.

Melberg, Arne. 2005. Resa och skriva. En guide till moderna resalitteraturen. Göteborg: Daidalos.

Moroz, Grzegorz. 2013. Travellers, Novelists and Gentlemen. Constructing Male Narrative Personae in British Travel Books, from the Beginnings to the Second World War. Frankfurt am Main: Peter Lang Edition.

Mørch, Dea Trier. 1968. Sorgmunter socialisme. Sovjettiske Raderinger. Rhodos.

-1970. Polen. Rhodos.

-1986. Da jeg opdagede Amerika. Vindrose. 
Petersson, Margareta. 1988. Indien I svenska reseskildringar 1950-1975. Lund: Lund University Press.

Richard, Anne Brigitte. 2003. [i:] Dansk kvindebiografisk leksikon. (digital udgave) http://www.kvinfo.dk/side/597/bio/1254/origin/170/query/m\%F8rch/ (15.03.2014).

Rifbjerg, Klaus. 1970. Fra Polen (anmeldelse af Polen). [i:] Politiken, 31.10.1970.

Rigney, Ann. 2007. Representation. [i:] Beller, Manfred \& Joep Leerssen (red.). Imagology. The cultural construction and literary representation of national characters. A critical survey. Amsterdam - New York: Rodopi, s. 415-418.

Rousseau, Jan Jakub. 1956. Trzy rozprawy z filozofii społecznej. (overs. af Henryk Elzenberg). Warszawa: Państwowe Wydawnictwo Naukowe.

Schab, Sylwia. 2008. Øjnene der ser... Om berøringsflader mellem kulturer og om det eksotiske i en "nær" udgave. Dansk (rejse-)litteratur om Polen", [i:] Grönstrand, Heidi \& Ulrika Gustafsson (red.) Gränser $i$ nordisk litteratur/Borders in Nordic Literature. IASS XXVI 2006, vol II, Åbo Akademis förlag, Åbo 2008, s. 652-659.

-2009. "Maria Hellebergs Fremmede naboer i den danske Polen-diskurs". Folia Scandinavica Posnaniensia nr 10, s. 113-122.

Sterne, Laurence. 1960. En følsom rejse gennem Frankrig og Italien. (overs. af Jens Kruuse). København: Hans Reitzel.

Søholm, Ejgil. 1991. Kunst der vil. Bogens verden, s. 389-390.

Thisted, Kirsten. 2011. For en "écriture anticoloniale". Kulturel oversættelse og litterære kodeskift i Ejersbos Afrikatrilogi. Kritik, nr. 199, s. 89-98.

Thomson, Carl. 2011. Travel Writing. London and New York: Routledge.

Wolff, Larry. 1994. Inventing Eastern Europe. The Map of Civilisation on the Mind of the Enlightenment. Stanford, California: Stanford University Press.

Zeidler-Janiszewska, Anna. 1999. Dryfujący flâneur, czyli o sytuacjonistycznym doświadczeniu miejskiej przestrzeni. [I:] Rewers, Ewa (red.). Przestrzeń, filozofia i architektura. Osiem rozmów o poznawaniu, produkowaniu i konsumowaniu przestrzeni, Poznań: Wydawnictwo Fundacji Humaniora, s. 127-140.

\section{Sylwia Izabela Schab}

Uniwersytet im. Adama Mickiewicza w Poznaniu

Katedra Skandynawistyki

Collegium Novum

al. Niepodległości 4

61-874 Poznań

Poland

sylwias@amu.edu.pl 